\title{
Early Warning System for Plant Nutrient Deficiency: Future Toolbox
}

\section{Srivastava AK}

National Research Centre for Citrus, Maharashtra, India

Plant nutritionists across the globe are on their toes to find ways and means to identify nutrient constraints as early in standing crop season as possible while dealing with perennial crops. Exciting progress has been made over the years, and accordingly, the basis of nutrient management strategy has experienced many paradigm shifts [1]. While doing so, it is being increasingly felt to have some diagnostic tool to identify nutrient constraint as and when it originates by capturing the signals released at sub-cellular level. On the other hand, conventionally used diagnostic tools of identifying nutrient constraints such as leaf analysis [2,3], soil analysis [4-6], juice analysis [7], and to some extent, metalloenzyme-based biochemical analysis [8], all have been under continuous use and refinement. But despite so much of genuine efforts worldwide, no one of these alone provides complete information, except the combined use of leaf and soil analysis, which are used on a comparatively wider scale [9-12]. Establishment of absolute figures of normal, deficient or excess nutrient level is not real, unless the dynamic aspect of leaf nutrient concentration is considered, especially when various nutrients interactions produce resonance within close space of tissue composition. Tertiary diagrams and nutrient ratios are early representation of interacting nutrients in the tissue compositional space [13].

Productivity of the plant depends essentially on the nutrient balance and the biological activity. There are definite limitations with the leaf analysis application which is largely dependent upon composition of index leaves or any other plant parts. On the other hand, overlapping phenotypic symptoms of plants deficient in N, S or Fe accompanied by lowered chlorophyll concentration makes the distinction between nutrients most often very difficult. Mechanistically, Fe and S are highly reactive components of many enzymes, and form active electron transfer agents like $\mathrm{Fe}_{2} \mathrm{~S}_{2}, \mathrm{Fe}_{3} \mathrm{~S}_{4}$ or $\mathrm{Fe}_{4} \mathrm{~S}_{4}$ clusters in form of thioredoxin/ ferredoxin reductase, ferredoxin-nitrite reductase, sulfite reductase, acotinase, succinate, phosphogluconate dehydrogenase to serve as sensors of oxidative stress [14]. Other example of Fe-deficiency showing typical chlorosis pattern due to interrupted chlorophyll synthesis may be cited, even though chlorophyll chelates $\mathrm{Mg}$ rather than Fe. Nutrient deficiency, thus, involves degradative changes in chloroplast components and additional cellular compartments. In the light of this information, an integrative physiological approach was suggested [15]. For example, the use of the peroxidase in the diagnosis of $\mathrm{Fe}$ - and Mn-deficiencies 8 prompted checking the utility of the method for citrus cultivars grown on differentially fertile soils. Parallel to what was observed with peroxidase, catalase, and aconitase reduced their levels of activity with Fe-deficiency and increased with Mn-deficiency, facilitated to establish the possibility of using the latter enzyme as an alternative mean of diagnosing Fe- and Mn-deficiencies [16]. In the early diagnosis of mineral deficiencies in lemon trees, aconitase has proved as precise as peroxidase, a specific Fe-metalloenzyme or even more so [17].

Studies [18] have shown that nutritional status of the responsive tissues transmits signals as a regulator of gene expression and at times, that can become a limiting factor in the process of plant development. There are other interesting improvements such as the determination of the nutrient evolution along the vegetative cycle, the substitution of the critical levels by the critical zone, fractionating the nutrient contents (especially the biologically active ones), and finally implementing the biochemical diagnosis. For the latter, the use of activities of specific enzymatic systems and also of metabolites concerned with photosynthesis has a good potential to improve the accuracy of nutrient constraint diagnosis over other conventional diagnostics. Many studies $[19,8]$ suggested that the levels of enzymatic activity could be effectively used as an alternative diagnostic tool to leaf analysis.

Not surprisingly, proximal sensing through spectral signatures of crop canopies in the field are more complex and often quite dissimilar from those of single green leaves measured under carefully controlled conditions. Even when leaf spectral properties remain relatively constant throughout the season, canopy spectra change dynamically depending upon variation in soil type, vegetation, and architectural arrangement of plant components. Vegetation indices provide a very simple yet elegant method for extracting the green plant quantity signal from complex canopy spectra. Narrower band indices such as the photochemical reflectance index, water band index, and normalized pigment chlorophyll ratio index are examples of reflectance indices that are correlated with certain physiological plant responses, and have promise for diagnosing water and nutrient stress [20]. Such studies hold promise for nutrient like nitrogen. Ironically, micronutrient deficiencies are diagnosed through specific pattern of chlorosis, e.g., $\mathrm{Fe}$ versus $\mathrm{Mn}$ or $\mathrm{Fe} / \mathrm{Mn}$ versus $\mathrm{Zn}$ backed up by nutrient concentration $[21,22]$ capturing symptomatic pattern of chlorosis via spectral norms (signatures) irrespective of crop species further limit this concept towards more wider application .

Functional analysis of the nutrients is, thus, based on the examination of certain molecular compounds linked with their functional activity. Plants possess enzymatic and non-enzymatic antioxidants in order to scavenge reactive oxygen species accumulated on account of nutrient stress. The enzyme antioxidants are superoxide dismutase, catalase, guaiacol per oxidase, glutathione peroxidase, ascorbate peroxidase, glutathione reductase, dehydroascorbate reductase and monodehydroascorbate reductase, while non-enzymatic antioxidants include reduced glutathione and ascorbate [23]. Application of nutrients like $\mathrm{N}, \mathrm{K}, \mathrm{Ca}$, and $\mathrm{Mg}$ reduce the toxicity of reactive oxygen species by increasing the concentration of antioxidants like superoxide dismutase; Catalase, and peroxidise in plant cells. These antioxidants scavenge the reactive oxygen species and reduce the photo-oxidation and maintain the integrity of chloroplast membrane for improved photosynthetic efficiency [24].

${ }^{*}$ Corresponding author: Srivastava AK, National Research Centre fo Citrus, Nagpur 440 010, Maharashtra, India, Tel: 09422458020; E-mail: aksrivas2007@gmail.com.

Received November 20, 2013; Accepted November 22, 2013; Published November 30, 2013

Citation: Srivastava AK (2013) Early Warning System for Plant Nutrient Deficiency: Future Toolbox. Agrotechnol 2: e106. doi:10.4172/2168-9881.1000e106

Copyright: (ㅇ 2013 Srivastava AK. This is an open-access article distributed under the terms of the Creative Commons Attribution License, which permits unrestricted use, distribution, and reproduction in any medium, provided the original author and source are credited. 
Specific nutrient-signalling pathways, such as Pi-signalling, and their regulatory systems in plants have been revealed, making it feasible to modify some key regulators(s) to enhance the uptake and use efficiency of the nutrient using functional genomics termed as plant nutriomics [25]. Nutrient mobility in the phloem from the leaves to the fruits and from the older to the younger fruits is reported in perennial crop like banana [26]. This will enable us to elucidate the functions and interactions of plant nutrients at the molecular, cellular, organ and even whole plant levels. Considering the thumping success of trunk nutrition, won't it be more advisable to analyse the xylem sap or phloem tissue for chemical and microbial constituents since the signal transduction for various nutrients functioning mediate through these tissues only. Such attempts could provide some meaningful clues about the presence or absence of those signals to be later utilized in understanding the underlying principles of nutrient stress induced warning mechanism. These studies could lay the solid foundation for developing some probe linked to transpiration stream of plant to act as early warning system for identifying deficiencies of various nutrients. In this regard, functioning of nutrients linked through metalloenzymes and enzyme antioxidants would be the target areas to uphold such novel possibilities.

\section{References}

1. Srivastava AK, Shyam Singh (2009) Citrus decline: Soil fertility and plant nutrition. Journal of Plant Nutrition 32: 197-245.

2. Srivastava AK, Shyam Singh (2005) Diagnosis of nutrient constraints in citrus orchards of humid tropical India. Journal of Plant Nutrition 29: 1061-1076.

3. Srivastava AK, Shyam Singh (2008) DRIS norms and their field validation in Nagpur mandarin (Citrus reticulata Blanco). Journal of Plant Nutrition 31: 1091 1107.

4. Srivastava AK, Shyam Singh (2001) Development of optimum soil property limits in relation to fruit yield and quality of Citrus reticulata Blanco cv. Nagpur mandarin. Tropical Agriculture 78: 174-181.

5. Srivastava AK, Shyam Singh (2002) Soil analysis based diagnostic norms for Indian citrus cultivar. Communications in Soil Science and Plant Analysis 33: 1689-1706.

6. Srivastava AK, Shyam Singh (2004) Soil and plant nutritional constraints contributing to citrus decline in Marathawada region, India. Communications in Soil Science and Plant Analysis 35: 2537-2550

7. Gallasch PT, Dalton GS, Ziersch J (1984) The use of juice analysis to define fertilizer requirements of citrus. In: Proceedings of the International Society of Citriculture, Sao Paulo, Brazil, 2: 140-142.

8. Srivastava AK, Shyam Singh (2006) Biochemical markers and nutrient constraints diagnosis in citrus: A perspective. Journal of Plant Nutrition 29: 827-855.
9. Mylavarapu RS (2010) Diagnostic nutrient testing. HortTechnology 20: 19-22.

10. Srivastava AK, Shyam Singh (2008) Citrus nutrition research in India: Problems and prospects. Indian Journal of Agricultural Sciences 78: 3-16.

11. Srivastava AK, Shyam Singh, Albrigo LG (2008) Diagnosis and remediation of nutrient constraints in citrus. Horticultural Reviews 34: 277-363.

12. Srivastava AK, Shyam Singh, Huchche AD, Lallan Ram (2001) Yield based leaf and soil test interpretations for Nagpur mandarin in Central India Communications in Soil Science and Plant Analysis 32: 585-599.

13. Parent Léon-Étienne (2011) Diagnosis of the nutrient compositional space of fruit crops. Rev Bras Frutic Jaboticabal SP 33: 321-334.

14. Flint DH, Allen RM (1996) Ironminus signSulfur Proteins with Nonredox Functions. Chem Rev 96: 2315-2334.

15. Imsande John (1998) Iron, sulfur and chlorophyll deficiencies: A need for an integrative approach in plant physiology. Physiol Plant 103: 139-144.

16. Valenzuela JL, Romero L (1988) Biochemical indicators and iron index for the appraisal of the mineral status in leaves of cucumber and tomato. Journal of Plant Nutrition 11: 1177-1184.

17. Garcia QL, Galindo L, Sanchez-Blanco MJ, Torrecillas A (1990) Peroxidase assay using $3,3^{\prime}, 5,5^{\prime}$ tetramethyl benzidine as $\mathrm{H}$-donor for rapid diagnosis of the iron deficiency in citrus. Scientia Hortic 92: 251-255.

18. Coruzzi G, Bush DR (2001) Nitrogen and carbon nutrient and metabolite signaling in plants. Plant Physiol 125: 61-64.

19. Tavdgiridze GN, Putkaradze Sh A (1991) Effect of different forms of nitrogen fertilizer on urease activity in mandarin leaves. Subtropicheskie Kul'tury 3: 5759.

20. Gamon JA, Serrano L, Surfus JS (1997) The photochemical reflectance index An optical indicator of photosynthetic radiation use efficience across species, functional types, and nutrient levels. Oecologia 112:492-501.

21. Srivastava AK (2013a) Nutrient deficiency symptomology in citrus: An effective diagnostic tool or just an aid for post-mortem analysis. Agricultural Advances 2: 177-194.

22. Srivastava AK (2013b) Nutrient diagnostics in citrus: Are they applicable to current season crop. Agrotechnology 2: 104-105.

23. Asada K (1992) Ascorbate peroxidase-a hydrogen peroxide scavenging enzyme in plants. Physiol Plant 85: 235-241.

24. Waraich EA, Ahmad R, Halim A, Aziz T (2012) Alleviation of temperature stress by nutrient management in crop plants: a review. Journal of Soil Science \& Plant Nutrition 12: 221-244.

25. Yan X, Wu P, Ling H, Xu G, Xu F, et al. (2006) Plant nutriomics in China: an overview. Ann Bot 98: 473-482.

26. Moreira A, Moraes LAC, Pereira JCR, Castro C (2007) Retranslocation of nutrients and zinc sulphate fertilization of banana plants in central Amazon. Journal of Applied Horticulture 9: 91-96. 